\title{
Thymic Epithelial Neoplasm
}

National Cancer Institute

\section{Source}

National Cancer Institute. Thymic Epithelial Neoplasm. NCI Thesaurus. Code C6450.

An epithelial neoplasm that affects the thymus gland. This category includes thymomas and carcinomas. 